\title{
DAMPAK PEMBANGUNAN PLTN TERHADAP PERUBAHAN TATA RUANG KABUPATEN JEPARA
}

\author{
Bambang Setiabudi \\ Program Studi Diploma III Teknik Sipil \\ Fakultas Teknik Universitas Diponegoro
}

\begin{abstract}
Bambang Setiabudi, in paper Study on effect of the NPP development toward spatial planning at District of Jepara had been done to support government policy according to governmental rule No. 5, Year of 2006 concerning National Energy Policy which nuclear energy is chosen as one of alternative energy source. The study was done by estimating growth of resident naturally with geometric method, increase of constructing labor pursuant to requirement of standard, and growth of resident as impact of economics growth and then to predict the land use change due to facilities requirement. Research result indicates that change of space pattern of non-agriculture settlement is equal to 15\%. It also shows that growth of resident density rises to level of 31-45 person per ha.
\end{abstract}

Keywords : spatial planning, geometric, input-output analysis, policy

\section{PENDAHULUAN}

Energi mempunyai peranan penting dalam pencapaian tujuan sosial, ekonomi, lingkungan dan untuk pembangunan berkelanjutan, serta merupakan pendukung bagi kegiatan ekonomi nasional. Penggunaan energi di Indonesia meningkat pesat sejalan dengan pertumbuhan ekonomi dan pertambahan penduduk. Sedangkan, akses ke energi yang andal dan terjangkau merupakan prasyarat utama untuk meningkatkan standar hidup masyarakat.

Melihat tingkat konsumsi energi dunia saat ini, penggunaan energi diprediksikan akan meningkat sebesar 70 persen antara tahun 2000 sampai 2030. Sumber energi yang berasal dari fosil yang saat ini menyumbang 87,7 persen dari total kebutuhan energi dunia, diperkirakan akan mengalami penurunan disebabkan tidak lagi ditemukannya sumber cadangan baru. Cadangan sumber energi yang berasal dari fosil diseluruh dunia diperkirakan hanya sampai 40 tahun untuk minyak bumi, 60 tahun untuk gas alam, dan 200 tahun untuk batu bara. Kondisi keterbatasan sumber energi di tengah semakin meningkatnya kebutuhan energi dunia dari tahun ketahun, serta tuntutan untuk melindungi bumi dari pemanasan global dan polusi lingkungan membuat tuntutan untuk segera mewujudkan teknologi baru bagi sumber energi.

Kegiatan studi kelayakan pembangunan PLTN di Indonesia telah dimulai sejak dilaksanakan seminar tentang kemungkinan adanya pembangunan PLTN di Indonesia yang dilaksanakan di Karangkates, Malang tahun 1976. Sejak saat itu giat dilaksanakan pemilihan calon tapak yang akan digunakan sebagai usulan tapak PLTN, kegiatan studi ekonomi, studi keselamatan dan teknologi PLTN dan lain sebagainya.

Dalam perkembangan
pemerintah telah mengeluarkan $\begin{array}{r}\text { Peraturan } \\ \text { Pemerintah No. 5, Tahun } 2006 \text { tentang Kebijakan }\end{array}$

Energi Nasional yang mengalokasikan kontribusi Energi baru terbarukan terhadap kebutuhan energi nasional sebesar $17 \%$ dan 5\% di antaranya berasal dari energi nuklir. Dengan mengasumsikan lokasi PLTN adalah di Ujung Lemahabang, Kabupaten Jepara, dilakukan kajian untuk mempelajari dampak pembangunan PLTN tersebut terhadap pola pemanfaatan ruang ditinjau dari kebutuhan sarana dan prasarana. Untuk itu perlu dikaji pertumbuhan penduduk selama proses pembangunan baik oleh pertumbuhan secara alamiah, pertambahan tenaga kerja, dan pertumbuhan penduduk akibat pertumbuhan ekonomi. Disamping itu kebutuhan lahan untuk PLTN juga menyebabkan terjadinya perubahan pola pemanfaatan ruang.

\section{TINJAUAN PUSTAKA \\ Tata Ruang}

Yang dimaksud dengan ruang adalah wadah yang meliputi ruang darat, ruang laut dan ruang udara, termasuk ruang di dalam bumi sebagai satu kesatuan wilayah, tempat manusia dan makhluk hidup lain melakukan kegiatan, dan memelihara kelangsungan hidupnya. Sedang tata ruang adalah wujud struktur ruang dan pola ruang.

Struktur ruang adalah susunan pusat-pusat permukiman dan sistem jaringan prasarana dan sarana yang berfungsi sebagai pendukung kegiatan sosial ekonomi masyarakat yang secara hierarkis memiliki hubungan fungsional. Pola ruang adalah distribusi peruntukan ruang dalam suatu wilayah yang meliputi peruntukan ruang untuk fungsi lindung dan peruntukan ruang untuk fungsi budi daya.

Rencana struktur ruang wilayah kabupaten meliputi sistem perkotaan di wilayahnya yang terkait dengan kawasan pedesaan dan sistem jaringan prasarana wilayah kabupaten, sedangkan rencana pola ruang wilayah kabupaten meliputi kawasan lindung kabupaten dan kawasan budi daya 
kabupaten. Kawasan lindung meliputi Kawasan Hutan Lindung, Kawasan Resapan Air, Kawasan Sepadan Pantai, Kawasan Sepadan Sungai, Kawasan Suaka Alam dan Kawasan Cagar Budaya. Kawasan Budidaya meliputi kawasan Pertanian yaitu Tanaman pangan lahan basah, Kawasan Lahan Kering, Kawasan tanaman tahunan atau perkebunan, kawasan hutan produksi, dan kawasan nonpertanian yaitu perikanan, peternakan, kawasan industri, kawasan pariwisata, kawasan pemukiman.

Secara alamiah dapat diperkirakan terjadi perubahan penggunaan lahan oleh kebutuhan penduduk akan sarana dan prasarana dan dampak pertumbuhan ekonomi terhadap penggunaan lahan. Oleh karena itu perubahan penggunaan lahan yang dibahas dalam makalah ini meliputi penggunaan ruang secara fisik untuk PLTN dan perubahan akibat pertumbuhan penduduk, ekonomi dan sarana prasarana.

\section{Energi Nuklir}

Pembangkit Listrik Tenaga Nuklir (PLTN) adalah stasiun pembangkit listrik thermal di mana panas yang dihasilkan diperoleh dari satu atau lebih reaktor nuklir pembangkit listrik. PLTN termasuk dalam pembangkit daya base load, yang dapat bekerja dengan baik ketika daya keluarannya konstan (meskipun boiling water reactor dapat turun hingga setengah dayanya ketika malam hari). Daya yang dibangkitkan per unit pembangkit berkisar dari $40 \mathrm{MW}$ hingga $1000 \mathrm{MW}$.

Di seluruh dunia saat ini ada 441 reaktor nuklir. Bahkan, sampai tahun 2020 PLTN akan bertambah 126 buah. Dari jumlah itu, 40 di antaranya berada di China. China sudah bertekad memanfaatkan PLTN yang murah, aman, dan bersih untuk memenuhi kebutuhan 1,3 miliar penduduknya. Di Negara lain, Prancis telah memenuhi 78 persen kebutuhan listriknya dari PLTN. Jepang juga, sekitar 40 persen kebutuhan listriknya diperoleh dari PLTN.

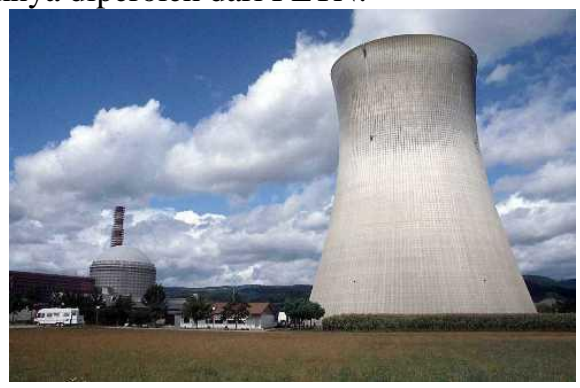

Gambar 1. Reaktor Nuklir

Memperhatikan kondisi perkembangan energi nuklir didunia, sudah saatnya pemerintah Indonesia kembali memprogramkan pembangunan reaktor nuklir dalam memenuhi kebutuhan energi nasional sebagaimana sudah pernah dirintis pada tahun 1976 lalu.

\section{Kebutuhan Lahan Pembangkit Tenaga Nuklir}

Beberapa studi dan seminar yang telah dilakukan oleh Komisi Persiapan Pembangunan PLTN (KP2PLTN), Badan Tenaga Atom Nasional (BATAN) dan Departemen Pekerjaan Umum dan Tenaga Listrik (Departemen PUTL) serta bekerja sama dengan beberapa perguruan tinggi, telah menghasilkan suatu keputusan bahwa Semenanjung Muria adalah lokasi yang paling ideal dan diusulkan agar digunakan sebagai lokasi pembangunan PLTN yang pertama di Indonesia.

Reaktor pembangkit tenaga nuklir hingga saat ini telah diproduksi dengan berbagai tipe/jenis seperti Reaktor Daya Air Ringan (Light Water Reactor), Pressurized Water Reactor (PWR), Boiled Water Reactor (BWR), VVER/RMBK, AGR, Advance Boiled Water Reactor (ABWR), AP 600, EPR. Dari berbagai jenis reaktor pembangkit tersebut, salah satu teknologi reaktor PLTN yang direncanakan akan digunakan dan dikembangkan di Indonesia adalah jenis Pressurized Water Reactor (PWR). Sehingga untuk pembahasan selanjutnya dalam makalah ini akan mengacu pada reaktor daya jenis PWR.

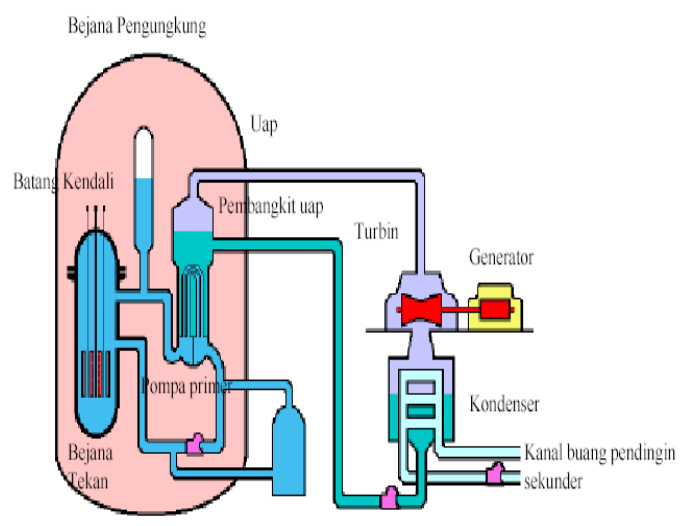

Gambar 2. Komponen utama reaktor jenis PWR, Sumber: http://contest.thinkquest.jp/

Komponen utama reaktor terdiri dari teras reaktor (fuel core), bejana tekan, batang kendali, kendali tekanan, dan pembangkit uap seperti terlihat pada Gambar 2.

- Teras reaktor yaitu susunan bahan bakar uranium sekaligus tempat terjadinya reaksi fisi yang menghasilkan energi dan bahan radionuklida yang sangat bersifat radioaktif.

- Komponen bejana tekan (pressure vessel), yaitu bejana tempat teras dan pendingin teras berada. Bejana ini diberi tekanan sedemikian rupa, sehingga pendingin tidak mengalami pendidihan sebelum sampai ke komponen pembangkit uap (steam generator).

- Pembangkit uap,

Pada pembangkit uap, pendingin primer dengan suhu dan tekanan tinggi berubah menjadi uap untuk disalurkan ke turbin. 
- Batang kendali berfungsi untuk mengendalikan daya reaktor dalam kondisi transient maupun tunak atau steady state.

- Kendali tekanan atau pressurizer digunakan untuk mengendalikan tekanan yang ada pada bejana tekan melalui dinamika fluktuasi ketinggian pendingin pada tabung pengontrol tekanan (pressurizer).

Seluruh komponen reaktor dikungkung dalam suatu pengungkung atau containment untuk menghindarkan pelepasan bahan radionuklida ke lingkungan, bila terjadi kecelakaan.

Komponen lain di luar reaktor adalah turbin dan generator yang digunakan untuk membangkitkan listrik, dan komponen kondensor beserta pompa feed water nya untuk sirkulasi air pendingin ke pembangkit uap dan heat sink. Untuk seluruh komponen reaktor diperlukan luas lahan sebesar 0.5 ha. Bila direncanakan di Jepara dibangun sebanyak 8 unit PLTN maka akan terjadi perubahan penggunaan lahan dari lahan pertanian ke lahan industri/gedung seluas 4 ha. Ketersedian lahan dan air untuk lokasi ini sangat penting untuk menjamin keandalan sistem pendingin reaktor maupun heat sink dari pengoperasian reaktor tersebut.

\section{PERUBAHAN PEMANFAATAN RUANG \\ Perubahan Pemanfaatan Ruang Untuk Pembangunan Kawasan PLTN}

Pembangunan PLTN secara fisik di Desa Balong, Semenanjung Muria menyebabkan perubahan pemanfaatan ruang di kawasan tersebut yaitu terjadinya konversi lahan dari lahan perkebunan menjadi lahan industri PLTN. Sesuai dengan skenario pembangunan Pembangkit Listrik Tenaga Nuklir di Ujung Lemahabang, maka untuk pertama kali akan dibangun 2 buah PLTN berkapasitas sedang yaitu 1000 MW. Selanjutnya akan dikembangkan sampai 8 unit dengan kapasitas total $7200 \mathrm{MW}$. Berdasarkan data dari hasil studi yang ada pada lokasi rencana PLTN, pada wilayah tersebut pemanfaatan ruang umumnya berupa tanah pertanian perkebunan, tidak banyak penduduk berada di lokasi tersebut.

Dengan demikian konversi lahan terjadi untuk tanah pertanian/perkebunan seluas $4.25 \mathrm{~km} 2$ di Desa Balong. Kawasan tersebut dipakai untuk masing-masing site terdiri dari gedung untuk Containment or Drywell Building, Auxiliary or Reactor Building, Turbine Building, Intake Structure or Screenhouse, Fuel Building, Diesel Generator Building (graphic).

\section{Perubahan Pemanfaatan Ruang Oleh \\ Pertumbuhan Penduduk \\ Pertumbuhan penduduk alamiah}

Dari data spasial terlihat bahwa wilayah wilayah ke arah utara yang semakin jauh dari Ibukota Kabupaten Jepara memiliki kerapatan yang rendah yaitu sekitar 1-16 jiwa per ha. Hal ini sesuai dengan hukum gravitasi bahwa semakin jauh lokasi dari suatu pusat bisnis (Center of Bussiness District) semakin kecil terasa pengaruh gaya tariknya. Perubahan waktu menyebabkan peningkatan pertumbuhan oleh penduduk yang secara nyata meningkatkan kepadatan penduduk.

Analisis pertumbuhan penduduk dilakukan untuk menghitung pertumbuhan akibat pertumbuhan alamiah, pertambahan tenaga kerja, dan pertumbuhan ekonomi Kabupaten Jepara. Pertumbuhan penduduk alamiah dilakukan dengan menggunakan persamaan :

$$
\mathrm{P}=\mathrm{Po}(1+\mathrm{i})^{\mathrm{r}}
$$

Keterangan :

$$
\begin{aligned}
& \mathrm{P}: \text { proyeksi jumlah penduduk } \\
& \mathrm{Po}: \text { jumlah penduduk awal } \\
& \mathrm{i} \quad \text { penelitian/studi } \\
& \mathrm{r}: \text { laju pertumbuhan penduduk, } \\
& \text { : pangkat yang menyatakan tahun }
\end{aligned}
$$

Hasil penelitian yang dilakukan Pusat Studi Ekonomi dan Kebijakan Publik UGM, berdasarkan data penduduk dari tahun 2000 sampai 2005 dan rata-rata persentasi pertumbuhan penduduk perkecamatan sebesar 2,67\%, maka perkiraan penduduk pada masing-masing kecamatan di Kabupaten Jepara secara geometri ditunjukkan pada Gambar 3.

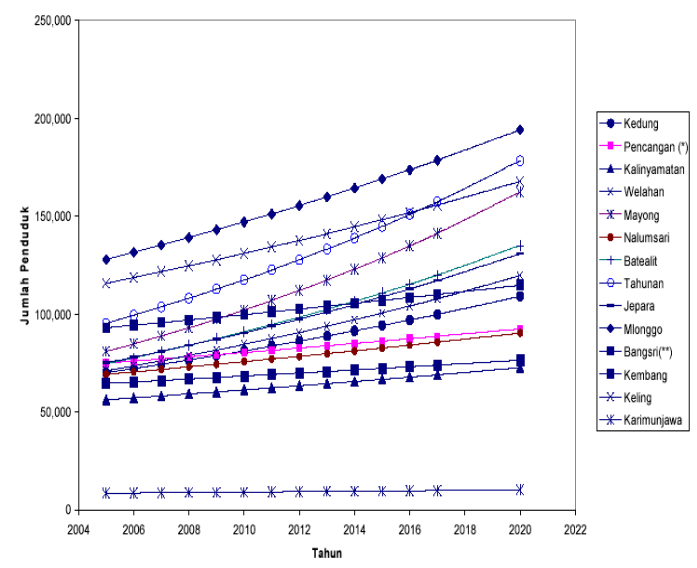

Gambar 3. Grafik Pertumbuhan Penduduk Kabupaten Jepara

\section{Penambahan penduduk akibat bertambahnya tenaga kerja \\ Penambahan penduduk akibat} bertambahnya tenaga kerja diestimasi berdasarkan perkiraan kebutuhan tenaga kerja untuk suatu PLTN dengan mengacu pada Technical Report Series No. 200 yang dikeluarkan IAEA. Secara grafik kebutuhan tenaga kerja tersebut ditunjukkan pada Gambar 3.2 dan Tabel 3.1, dengan mengasumsikan jadwal pembangunan PLTN seperti diagram pada Gambar 3.3. 


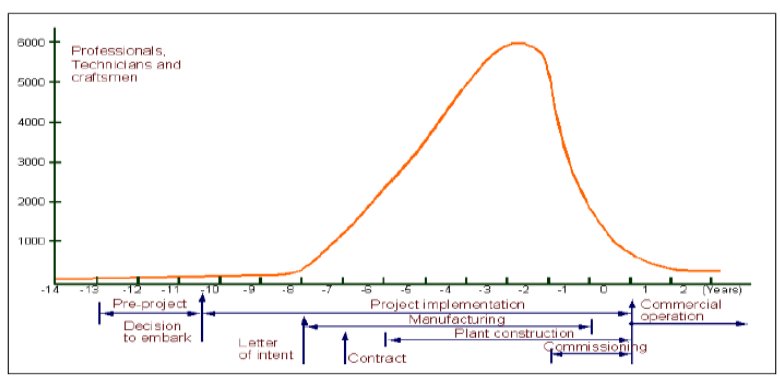

Gambar 4. Grafik Kebutuhan Tenaga Kerja Untuk Pembangunan PLTN 1000 MW

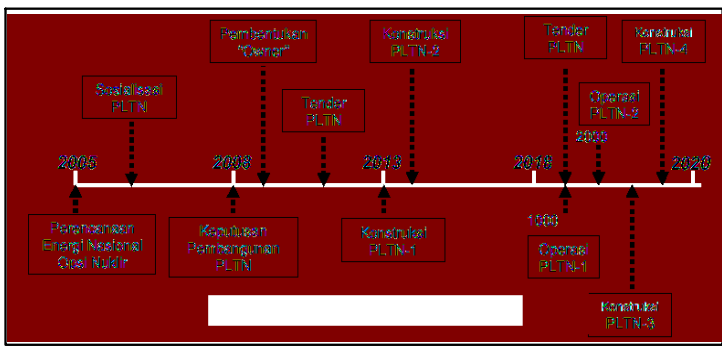

Gambar 4. Jadwal Pembangunan PLTN 1000 MW

Oleh kehadiran PLTN selama masa pembangunan, menyebabkan kepadatan penduduk meningkat khususnya di kecamatan Kembang, karena di kecamatan inilah akan terkonsentrasi banyak pekerja pembangunan PLTN dan pekerja lain yang mendukung kegiatan pembangunan tersebut seperti pedagang barang-barang bangunan, pedagang makanan, pedagang asongan, penawar jasa, petugas rumah sakit, polisi dan banyak lainnya. Dalam analisis ini diasumsikan 60\% pekerja akan tinggal di Kecamatan Kembang dan Kecamatan tetangga masing-masing sebanyak $10 \%$.

Diproyeksikan jumlah penduduk pada tahun 2020, bila tidak dilakukan pembangunan PLTN adalah sebesar 1.654 .396 jiwa, sedangkan bila pembangunan PLTN dilakukan sejak 2008 maka jumlah penduduk berkisar 1.898.124 jiwa. Artinya perbandingan dampak perubahan lahan secara fisik oleh kehadiran PLTN adalah sebesar 15\%. Disisi lain pertumbuhan kebutuhan lahan pekarangan untuk pemukiman juga mengalami peningkatan yang sangat besar. Hal ini akan berdampak pada konversi lahan ke lahan pemukiman dan perkantoran.

\section{Kebutuhan Sarana dan Prasarana}

Sejalan dengan perkembangan penduduk tersebut maka kebutuhan sarana dan prasarana juga meningkat. Dalam menganalisis kebutuhan sarana dan prasarana ini digunakan standar Pedoman Teknik Analisis Tata Cara dan Pedoman Teknik Baku Perencanaan Tata Ruang yang dikeluarkan oleh Departemen Pekerjaan Umum. Proyeksi kebutuhan lahan untuk sarana dan prasarana meliputi perumahan, pendidikan, kesehatan, peribadatan, kantor, perdagangan, keamanan, hiburan, parkir umum dan taman bermain. Dari data hasil studi sebelumnya menunjukkan bahwa pertumbuhan kebutuhan lahan apabila tidak ada pembangunan PLTN adalah sebesar 29.849.598 $\mathrm{m}^{2}$, sedangkan dengan pembangunan PLTN kebutuhan lahan untuk sarana dan prasarana diproyeksikan akan meningkat menjadi $40.876 .132 \mathrm{~m}^{2}$. Apabila dibandingkan dengan luas lahan pekarangan yang tersedia yaitu 28.269.382 $\mathrm{m}^{2}$, maka besar kemungkinan akan terjadi konversi lahan yang sangat signifikan.

Dengan perencanaan tata ruang yang baik maka perubahan jalan dan penyiapan sarana-sarana yang memiliki faktor penurunan dosis radiasi yang cukup tinggi dapat mengurangi dampak risiko bila terjadi kecelakaan yaitu dengan tersedianya sheltering yang cukup dan jalur evakuasi yang terencana.

\section{KESIMPULAN}

Pembangunan PLTN memiliki dampak ekonomi bukan hanya pada satu sektor perekonomian tetapi berbagai sektor. Permintaan untuk pemenuhan kebutuhan pembangunan PLTN telah berdampak pada meningkatnya penyediaan lahan pertanian maupun lahan panen sebesar $4-11 \%$ dibandingkan pertumbuhan secara alamiah. Dengan demikian pembangunan PLTN berkontribusi merubah pola pemanfaatan ruang kawasan budi

Tabel 1 Kebutuhan Tenaga Kerja dalam Pembangunan Satu Unit PLTN

\begin{tabular}{|l|c|c|c|c|c|c|}
\hline \multirow{2}{*}{ Tahapan Kegiatan } & \multicolumn{2}{|c|}{ Profesional } & \multicolumn{2}{c|}{ Magister/Sarjana Teknik } & \multicolumn{2}{c|}{ Strata } \\
\cline { 2 - 7 } & Min & Max & Min & Max & S1 & S2 \\
\hline Pre Project & 37 & 55 & 27 & 38 & 37 & 1 \\
\hline Project Manajemen Utility & 51 & 67 & 41 & 53 & 47 & 6 \\
\hline Kontraktor utama & 30 & 40 & 25 & 33 & 25 & 8 \\
\hline Project Engineering & 180 & 240 & 180 & 240 & 238 & 2 \\
\hline Proqurement & 16 & 26 & 13 & 20 & 12 & 8 \\
\hline Aktivitas QA/QC & 30 & 50 & 30 & 50 & 49 & 1 \\
\hline Konstruksi & 70 & 100 & 67 & 95 & 94 & 1 \\
\hline Komisioning & 38 & 50 & 38 & 50 & 49 & 1 \\
\hline Operasi dan Pemeliharaan & 50 & 73 & 50 & 73 & 51 & 22 \\
\hline
\end{tabular}


daya pertanian Kabupaten Jepara dalam kisaran 4$11 \%$.

Pertumbuhan penduduk dengan kehadiran PLTN meningkat sebesar 1,15 kali lipat dibanding pertumbuhan penduduk secara alamiah. Hal ini berarti kontribusi pembangunan PLTN terhadap perubahan pola pemanfaatan ruang kawasan budi daya non-pertanian pemukiman adalah sebesar $15 \%$ persen. Dengan kehadiran PLTN di Desa Balong Kecamatan Kembang maka tingkat pertumbuhan penduduk sangat besar sehingga memiliki tingkat kepadatan kategori ke 3 yaitu antara 31-45 jiwa per ha. Oleh karena itu prioritas pembangunan sarana dan prasarana perlu diberikan pada wilayah ini.

Disisi lain peningkatan yang sangat besar di Kecamatan Kembang dan Kecamatan terdekat lainnya dapat mendorong peningkatan risiko bagi penduduk sekitar PLTN. Oleh karena itu sangat diperlukan kebijakan-kebijakan yang terpadu untuk mengelola pembangunan sarana dan prasarana, pemanfaatan lahan dan kekayaan sumber daya alam Kabupaten Jepara sehingga terdapat keseimbangan pembangunan antar wilayah kecamatan di Kabupaten Jepara. Dengan keseimbangan pembangunan antar wilayah kecamatan ini diharapkan penduduk dapat terdistribusi secara merata di berbagai wilayah Kecamatan.

\section{DAFTAR PUSTAKA}

1. BAPEDA Dan BPS Kabupaten Jepara, 2005, Produk Domestik Regional Bruto Kabupaten Jepara, Jepara.

2. BAPEDA Dan BPS Kabupaten Jepara, 2001, Tabel Input Output Kabupaten Jepara 2001. BPS Kabupaten Jepara.

3. BPS, 2000, Kerangka Teori Dan Analisis Tabel Input-Output, ISSN.0251039506330.9501.

4. BPS KAB. JEPARA, 2002, Jepara Dalam Angka 2002. BPS Kabupaten Jepara.

5. BPS KAB. JEPARA, 2005, Jepara Dalam Angka 2005. BPS Kabupaten Jepara.

6. BPS KAB. JEPARA, 2006, Jepara Dalam Angka 2006. BPS Kabupaten Jepara.

7. DEPARTEMEN PEKERJAAN UMUM, 2007, Undang-Undang No. 26 Tahun 2007 Tentang Penataan Ruang, Jakarta.

8. HENI SUSIATI \& JUPITER SITORUS PANE, 2007, Prosiding Seminar Nasional Teknologi Pengolahan Limbah.

9. IAEA, 1988, Nuclear Power Project Management. A Guide Book, Technical Report Series No. 200, Vienna. Austria.

10. PEMERINTAH REPUBLIK INDONESIA, 2006, Peraturan Pemerintah No. 5 Tahun 2006, Kebijakan Energi Nasional, Jakarta.

11. PUSAT STUDI EKONOMI DAN KEBIJAKAN PUBLIK UGM, 2004, Kajian Dampak Ekonomi Pembangunan PLTN Terhadap Sektor Ekonomi Nasional, Jogyakarta.

12. RUSTIADI E, SUNSUN S, DYAH P. , 2004, Perencanaan Pengembangan Wilayah. Konsep Dasar Dan Teori. IPB Bogor. 